\title{
Social media marketing of pharmacies across the Republic of North Macedonia
}

\author{
Goran Pop - Nikolov ${ }^{1}$, Aleksandra Kapedanovska Nestorovska ${ }^{2}$, Zorica Naumovska ${ }^{2}$, \\ Ljubica Suturkova ${ }^{2}$, Zoran Sterjev ${ }^{2}$
}

${ }^{1}$ Alkaloid AD, Pharmaceutical, Chemical and Cosmetics Company, Aleksandar Makedonski 12, 1000 Skopje, Republic of North Macedonia

${ }^{2}$ Ss. Cyril and Methodius University in Skopje, Faculty of Pharmacy, Majka Tereza 47, 1000 Skopje, Republic of North Macedonia

Received: December 2020; Accepted: March 2021

\begin{abstract}
Internet marketing or digital marketing, is the fastest growing type of promotion for brands and companies to connect with potential customers. There are as many specializations within digital marketing as there are ways of interacting using digital media. This study evaluates and describes the usage of social media marketing as most common type of digital marketing used for self-promotion of the pharmacy sector in the Republic of North Macedonia. Social media marketing is raising brand awareness by engaging people in discussion online. The most popular platforms for social media marketing are Facebook and Instagram. For the purpose of the analysis, data from social network profiles Facebook and Instagram and from the websites of the 1000 pharmacies is used. This data includes: profile content, frequency of posts of health related articles and products, presence of relevant information and links to sites from which the content is shared, frequency of posting offers and sales at the pharmacy. The conducted research shows that the use of Internet as a digital marketing tool in Republic of North Macedonia is not sufficiently developed, especially when websites are used as a marketing tool for promotion of the pharmacy business and their services. The results show that Facebook as social media is used most frequently for posting health advices, promotion of new products and answering customer's questions. Promotion of the professional pharmaceutical services is lower than the promotion of products. This leads to insufficient data for the implementation of the principles of evidencebased medicine in daily practice.
\end{abstract}

Keywords: Internet marketing, digital marketing, social media marketing, promotion, pharmacies, Facebook, Instagram, website

\section{Introduction}

In the past few years, the importance of Internet as a medium for exchange of information and a powerful communication channel has considerably increased. Taking this into account, Internet became an excellent place for carrying out marketing research, identifying consumers' needs, decision making, marketing, promotion and distribution of products (Shyu et al.,
2015).

Digital marketing entails promoting products or services by using digital technologies mostly on Internet portals, but also including commercials, mobile devices and other digital media. Starting from the 1990s, the development of digital marketing has changed the way in which many brands and business are being advertised. With the rise of digital platforms in companies' everyday marketing plans, digital marketing has become a considerable tool for promoting and securing quality

\footnotetext{
* thepopce7@gmail.com
} 
information and services from the companies to the consumers.

Methods that are used in digital marketing, such as search engine marketing, content marketing, influencer marketing, campaign marketing, social media marketing, e-mail direct marketing, display advertising, are becoming more prevalent marketing types in the world (Armstrong and Kotler, 2007).

Social marketing, as one of the methods of digital marketing, can be defined as pertaining marketing strategy through the social networks in order to raise the awareness of a particular business and increase the number of followers (future consumers) in the social media. Considering that, social marketing became an integral part of people's lives and it is not unexpected that this marketing could replace the traditional marketing strategies. Additionally, it offers quite easy interaction with the ultimate users, demands shorter engagement and is more cost-effective in comparison with marketing itself (Techopedia, 2015).

Content marketing, as one of the strategies for successful marketing, defined as a delivery of a certain content about the product or the service that the user is searching, i.e., providing information to target audience, can be easily conducted through in the social media, as a joint method with the social marketing.

Relevant data confirmed that more than $60 \%$ of the time on the Internet users spend on social media which should serve as a solid indicator that the marketing of the relevant products and services should be directed through these media (PEW Research Center, 2018).

Among the most widely used social media by businesses are: Facebook, Instagram, LinkedIn, Twitter and websites.

Bearing all this in mind, many companies increased the investment in the field of digital marketing, expecting that online environments will become an important platform for health promotion and distribution of quality health services. As a result, the health services market gained good connectivity and interdependent exchange of information, while the competition strived to provide highest quality services for its consumers.

From the healthcare point of view, the massive use of social media daily impacts the communication among patients, doctors, and health organizations, allowing the users to be connected and easily share relevant medical information as well (Taiminen and Karjaluoto, 2015).

Table 1. Number of pharmacies in the cities in the Republic of North Macedonia presented in percent

\begin{tabular}{|c|c|c|}
\hline City & $\begin{array}{l}\text { Number of } \\
\text { pharmacies }\end{array}$ & $\begin{array}{c}\% \text { of total number of pharmacies in } \\
\text { Republic of North Macedonia }\end{array}$ \\
\hline Skopje & 256 & $25.6 \%$ \\
\hline Tetovo & 93 & $9.3 \%$ \\
\hline Kumanovo & 67 & $6.7 \%$ \\
\hline Bitola & 65 & $6.5 \%$ \\
\hline Gostivar & 46 & $4.6 \%$ \\
\hline Prilep & 46 & $4.6 \%$ \\
\hline Ohrid & 38 & $3.8 \%$ \\
\hline Struga & 37 & $3.7 \%$ \\
\hline Strumica & 33 & $3.3 \%$ \\
\hline Veles & 29 & $2.9 \%$ \\
\hline Kicevo & 25 & $2.5 \%$ \\
\hline Kavadarci & 25 & $2.5 \%$ \\
\hline Stip & 21 & $2.1 \%$ \\
\hline Kocani & 20 & $2 \%$ \\
\hline Gevgelija & 15 & $1.5 \%$ \\
\hline Radovish & 11 & $1.1 \%$ \\
\hline Vinica & 10 & $1 \%$ \\
\hline Other towns & 173 & $17.3 \%$ \\
\hline Total & 1000 & $100 \%$ \\
\hline
\end{tabular}


Research showed that almost half of the Internet users most often search health related topics and the retrieve information considerably impact their decision for subsequent treatment and use of medical products (Shyu et al., 2015).

Pharmacies, although with certain limitations, with the arrival of the digital marketing era, struggle to follow the trend along with the other small businesses and to promote their services and products through social media. Implementation of digital marketing in the field of pharmacy is limited by few obstacles, such as promotion of products with suspicious quality, giving advices by non-health care professionals resulting with users' lack of information and knowledge, as well as not fulfilling the highly important set of criteria (Credibility, Content, Disclosure, Links, Design and Interactivity) inevitable when publishing health information on the web.

Considering the digital marketing's impact, the aim of this paper is to evaluate and describe the use of social/digital marketing in the pharmacy sector in the Republic of North Macedonia and evaluating the quality of health information used in marketing.

\section{Materials and methods}

The study was conducted in the period from November, 2019 until April, 2020 and included total of 1000 pharmacies in the Republic of North Macedonia (according to the data available on the website of the Central Register of Medications https://lekovi.zdravstvo.gov.mk/). Most of the pharmacies, 256 or $25.6 \%$ of the total number of pharmacies in our country are located in Skopje. 119 pharmacies in Skopje, or $46 \%$ are part of pharmacy chains (Zegin - 61 and Eurofarm - 58 pharmacies). The remaining pharmacies are part of smaller pharmaceutical chains such as: Viola - 11 pharmacies, Galenium Pharm 8 pharmacies, Alpi Pharm -8 pharmacies, Herba -7 pharmacies, Gold Moon - 6 pharmacies, and other chains with 5 or less than 5 pharmacies or individual pharmacies. All the pharmacies in the Republic of North Macedonia are private. Table 1 summarizes the regional pharmacy distribution classified by the city in our country.

Identification of the pharmacies with their own website location and social network profiles was conducted through a search engine (Google) using the following keywords: pharmacy, pharmacies in Republic of North Macedonia, pharmacy, pharmacies in Macedonia, "barnatore", "eczane”, pharmacy Macedonia. Contents of the websites, type of information presented to end users and sources of information were evaluated in this study. Data used for the analysis of pharmacies social networks profiles were extracted from their Facebook and Instagram business pages and included the following: profile content, frequency of posts of health-health related articles and products, presence of relevant information and links to certain sites from which the content was shared, type of products they market directly to consumer (only products that they individually import or products from all the companies that are present in the market), frequency of posting offers and sales at the pharmacy.

\section{Results}

Identification of the pharmacies that have their own websites and social network profiles

Upon the completion of the internet and social media searches, it was confirmed that there were 18 active websites. The following are the pharmacies with professional websites: PHI Eurofarm, PHI Zegin, PHI Viola, PHI Via Farm, PHI Sara Farm, PHI Anni Pharm, Beti Pharmacies - pharmaceutical organization, Plus Pharma - pharmaceutical organization, PHI Promedika, PHI Danea Pharm, 24-hours online pharmacy, PHI FILA, PHI Medipharm, Herbal Pharmacy - Skopje, PHI Medica Plus, PHI Pentamedika, PHI Oskar Lek, PHI Varufarm. Web locations of the pharmacies with the following links are listed in Table 2.

535 pharmacies or i.e., $53.5 \%$ of the total number of pharmacies in our country (single or part of the chain) have personal websites as a source of information for their consumers. $67 \%$ or 670 pharmacies in Republic of North Macedonia use Facebook as a tool for informing their consumers and total of 520 pharmacies have both website and Facebook profile. Self-promotion and informing of the potential consumers through the Instagram are represented less than Facebook. Instagram profiles of 236 pharmacies, i.e., $23.6 \%$ of the total number of pharmacies in our country were identified in our study. It is important to notice that $33 \%$ or 330 pharmacies in Republic of North Macedonia do not use any of the above-mentioned tools to connect and share information with their consumers (Table 3). Evaluation of the content being presented on the websites
of pharmacies in the Republic of North Macedonia

The most commonly presented information on the home page of the evaluated pharmacies' websites are:

- Contact - 85\% (contact information - phone, email);

- About us - $75 \%$ (information related to the pharmacy);

- Products - 45\% (information about products portfolio and new products on the market);

- Pharmacies - 40\% (information about the number of pharmacies in the chain);

- Newsletter - 25\% (health related information for the consumers);

- News - 25\% (news about treatment of certain health conditions);

- Pharmacy locator - 20\% (map of the pharmacies and their exact location);

Макед. фарм. билт., 66 (2) 87 - 93 (2020) 
Table 2. List of active websites from the pharmacies in the Republic of North Macedonia

\author{
js://aptekieurofarm.com.mk/ \\ o://www.zegin.com.mk/ \\ o://www.promedika.com.mk/mk-mk/PharmacyStore \\ o://www.remedika.com.mk/apteka-danea-farm/ \\ js://24apteka.mk/ \\ $\underline{\text { ss://zmc.mk/services/fila-apteka/ }}$ \\ o://annifarm.mk/ \\ os://www.clubeconomy.com.mk/sarafarm \\ o://primdrsamardziski.mk/Apteka.html \\ os://betty.mk/apteki-betty/ \\ o://bilnaapteka.com.mk/ \\ j://www.medicaplus.com.mk/ \\ o://www.interevrogeneks.com/en/pharmacy/ \\ o://pharmacypentamedika.mk/en \\ o://viafarm.mk/ \\ j://www.oskarlek.mk/ \\ j://pluspharma.mk/apteki/ \\ $\underline{\text { os://viola.mk/ }}$
}

- Advice - 15\% (health advices provided by reliable sources and experts in the specific area).

The pharmacies that are using internet marketing as a communication tool with their consumers, most often post information for new over-the-counter products that come to the market, food supplements and "borderline" products. The search did not show the presence of shared drug information that cannot be advertised under the current medicines act in the Republic of North Macedonia.

Pharmacies' websites and social media profiles, most frequently include educational, popular content with regards to health promotion, advices for maintaining healthy life style, healthy diet, health professionals' advices associated with particular disease state etc.

Only 6 out of 18 active websites cite the original sources of the presented information on their web location. The analysis of the sources and documentation published showed heterogeneity. Most of the weblocations (PZU Eurofarm, PZU Zegin, Beti and Plus Pharma) acknowledge the profile of health professional that has contributed the written text. Others, (Dna Anni Pharm) state the sources of presented information and a relevant link to the scientific publication where the information was taken from is obtained.

The published educational content may be found on the following websites:

https://aptekieurofarm.com.mk/features/nashi-soveti/, http://zegin.com.mk/home/articles-overview.html, http://pluspharma.mk/soveti/,

https://betty.mk/category/soveti-za-vasheto-zdravje/, http://annifarm.mk/soveti-i-predlozi/, https://viola.mk/novosti/.

Some of the pharmacies use printed and electronic newsletters that they publish periodically for their consumers. The professional newsletters that are published by the pharmacies in our country are: Semejno zdravje (https://aptekieurofarm.com.mk/semejnozdravje/), Vas aptekar (http://vasaptekar.mk/index.php /magazin), Betty magazine (https://betty.mk/bettymagazin-jun-2019/), Viola magazine (https://viola.mk/ viola-magazin/), Mali soveti za zdravo semejstvo (http://zegin.com.mk/home/magazines.html), Nase zdravje (http://viafarm.mk/category/\%d0\%bd\%d0\%b0\%d1\%88\% d0\%b5-\%d0\%b7\%d0\%b4\%d1\%80\%d0\%b0\%d0\%b2\%d1 $\% 98 \% \mathrm{~d} 0 \% \mathrm{~b} 5 /)$.

Those newsletters contain information about new products on the market in the Republic of North Macedonia, expert advice for patients, as well as commercials about the products and monthly offers by the pharmacies. The newsletters include a heterogeneous group of pharmaceuticals, represented by the companies that own the pharmacies, in addition to products from other manufacturers on the pharmaceutical market.

Regarding the periodic renewal of the information 
Table 3. Use of social media by pharmacies for self-promotion and information sharing with consumers in the Republic of North Macedonia

\begin{tabular}{ccccc}
\hline Type of social media & Facebook & Website & Instagram & No tool used \\
\hline $\mathrm{n}(\%)$ & $670(67 \%)$ & $535(53.5 \%)$ & $236(23.6 \%)$ & $330(33 \%)$ \\
\hline
\end{tabular}

available to all companies, there has been a recovery of more than 1 month with the exception of the PHI Viola Pharmacy website, where the latest update was made in October 2019.

\section{Evaluation of the content being presented on social business profiles}

The pharmacies that use a Facebook page as a marketing tool, mostly publish about new products, articles and other services at various intervals. Within a 6month timeframe, $2 \%$ of the pharmacies post daily on their Facebook profiles (Zegin, Beti, and Dna Anni Pharm) or post every other day (Viola, Viapharm and Eurofarm). Nearly 40\% (50 pharmacies) that have a Facebook page post once a week, whereas the rest of the pharmacies $(56 \%)$ do not use Facebook at all to publish any kind of information for longer periods of time.

Facebook is also used as a tool for two-way communication with the patients through answering their questions, which is a common practice of the patients and those questions are related to certain products, symptoms and conditions. The most frequently asked questions by the patients are: whether certain products are available in certain pharmacies in cases when those products are not included on the profile, the price of the specific product, directions for use of a product, recommendation for the type of product to use for certain symptoms (headache, cold, diarrhea) and advice for side effects of medications. The pharmacies that use Facebook actively for promotion provide answers to consumer questions within period of 30 minutes - 24 hours. The posts that the pharmacies make on their Facebook profiles include promotion of new products at the pharmacy, health advice and outcomes related to the use of certain products, monthly offers and price reductions of certain products.

The pharmacies that are part of a certain chain, on their Facebook profile often post about and favor products that are imported and distributed by them. Usually, post for a certain product contains: a picture of the product packaging, product price, description for product use and certain text with health information by an expert (doctor, pharmacist or dentist) or information taken from certain relevant source. The pharmacies' posts on their websites sometimes contain a video commercial for the specific product and most of the posts that are on the page are carefully created so that they attract the ultimate consumers which would then lead to more "likes" or "shares" for that specific product. Also, information about different services such as rewards cards, monthly offers and expert advice are included in the posts for their consumers.

The pharmacies that are not a part of a chain, on their Facebook profile post about products from different manufacturers for which they have price reduction or monthly offers. Most common are posts about products that are connected to certain time period in the year (eg. during the summer period, there are more frequent posts about sunscreen with protection factor, gels against insect bites, products that are necessary for summer vacations, probiotics, products for diarrhea and other products). Every post contains an informative text about the use of the specific product, advice about the conditions that are typical for that time of the year (e.g., sunburns, diarrhea, insect bites) and product price. However, they rarely contain information about the source of information and are most commonly written as general health information about the use of the specific product.

\section{Discussion}

The use of marketing on social media starts by observing and understanding the habits of the target audience and it also includes the choice of social media that is appropriate for promotion to the ultimate consumers. It is necessary to carry out an analysis of the competitors and their approach to social marketing, to identify the number of posts, number of followers, frequency of publishing certain information and the average number of comments and likes for every post.

It is also important to pay attention to how they position their business on the social media in order to create something similar or something completely different in order to be unique.

The conducted research showed that the use of Internet opportunities and social networks as a marketing tool in Republic of North Macedonia is still not sufficiently developed. This especially applies to the use of websites as a marketing tool for self-presentation, promotion of products and pharmacy services. The pharmacies in the Republic of North Macedonia most often use Facebook as a tool to connect with their consumers, whereas the use of Instagram as a marketing tool has risen in the past year.

Companies that have developed a pharmacy chain are much more likely to use the marketing tools available 
over the Internet compared to small single pharmacies. The pharmacies that are registered in the capital of the country Skopje are more represented on the Internet compared to the pharmacies from other cities in the country.

The promotion of professional pharmaceutical services and services is several times lower than the promotion of products.

Of particular concern is the fact that insufficient data can be found regarding to the sources of information used to create social networking websites and profiles that cast doubt on the implementations of the principles of evidence-based medicine in daily practice.

In general, the conducted research has indicated that the marketing tools that are available on the Internet and through social networks by the pharmacies in Republic of North Macedonia is still not sufficiently used as marketing tools.

\section{Conclusion}

Digital marketing has marked significant development in the past few years, offering many brands and businesses to be advertised on Internet and social networks. However, the use of digital marketing as a tool from the pharmacies in Republic of North Macedonia is still not sufficiently developed. Social networks like Facebook and Instagram are mostly used by pharmacies for promotion of pharmaceutical products compared with promotion of professional pharmaceutical services. The use of web-sites by pharmacies in providing professional health advices is very low. Information they provide on the web-sites are often published as general health information without listed sources from where they were obtained.

Taking into account that digital marketing in pharmaceutical sector is growing every day, it is expected for the pharmacies in Republic of North Macedonia in the future to increase and improve use of online platforms for promotion and distribution of quality health services by providing health information for pharmaceutical products from evidence-based medicine to the end users.

\section{References}

Gerber, M.E., 2004. Small business: The E-Myth Revisited. Harper Business. Available at: https://www.samuelthomasdavies.com/booksummaries/business/the-e-myth-revisited/.

Jain, E., Yadav, A., 2017. Marketing and Technology: Role of Technology in Modern Marketing. Journal of Business and Management. 19(5), 49-53. Available at: http://www.iosrjournals.org/iosr-jbm/papers/Vol19issue5/Version-6/I1905064953.pdf.

Kates, M., 2013. Making digital and traditional marketing work together. Econsultancy. Available at: https://econsultancy.com/making-digital-and-traditionalmarketing-work-together/ (last access: 20.12.2020).

Kim, A.J., Johnson Kim, K.P., 2016. Power of consumers using social media: Examining the influences of brand-related user-generated content on Facebook. Computers in Human Behavior 58, 98-108. Available at: https://doi.org/10.1016/j.chb.2015.12.047.

Kotler, P.T., Armstrong, G., 2008. Principles of Marketing. 12th ed. Toronto: Pearson Prentice Hall.

Kotler, P.T., Keller, L.K., 2015. Marketing Management, 15th ed. Upper Saddle River, N.J. Pearson Prentice Hall.

PEW Research Center, 2018. Social Media Use in 2018. Available at: https://www.pewresearch.org/internet/2018/03/01/socialmedia-use-in-2018/ (last access: 20.12.2020).

Scott, D., 2015. The New Rules of Marketing and PR: How to Use Social Media and Viral Marketing to Reach Buyers Directly, 5th ed. Wiley. Available at: https://www.nima.today/wp-content/uploads/2018/11/TheNew-Rules-Of-Marketing-And-Pr-David-MeermanScott.pdf.

Shyu, M.L., Chiang, W.J., Chien, W.Y., Wang, S.L., 2015. Key success factors in digital marketing in service industry and the development strategies: A case study on Fleur de Chine at Sun Moon Lake. The International Journal of Organizational Innovation 8(1), 172-185.

Sisodiya, P and Sharma, G., 2018. Digital marketing: Technology and Impact on Business and Management. JETIR 5(12), 714-720.

Taiminen, H.M., Karjaluoto. H., 2015. The Usage of Digital Marketing Channels in SMEs. Journal of Small Business and Enterprise Development 22(4), 633-651. 


\title{
Употреба на маркетинг преку социјалните медиуми на аптеките во Република Северна Македонија
}

\author{
Горан Поп-Николов ${ }^{1}$, Александра Капедановска Несторовска ${ }^{2}$, \\ Зорица Наумовска ${ }^{2}$, Љубица Шутуркова ${ }^{2}$, Зоран Стерјев ${ }^{2}$ \\ ${ }^{1}$ Алкалоид АД, Фармачевтска, Хемиска и Козметичка Индустрија, \\ Александар Македонски 12, 1000 Скопје, Република Северна Македонија \\ ${ }^{2}$ Универзитет „Св. Кирил и Методиј“ во Скопје, Фармацевтски факултет, \\ Мајка Тереза 47, 1000 Скопје, Република Северна Македонија
}

Клучни зборови: Интернет маркетинг, дигитален маркетинг, маркетинг преку социјални медиуми, промоции, аптеки, Фејсбук, Инстаграм, веб страни

Интернет или дигиталниот маркетинг е најбрзо растечки вид на маркетинг кој служи за промоција на производите и поврзување на компаниите со потенцијалните клиенти. Во рамките на дигиталниот маркетинг спаѓаат повеќе типови на маркетинг во зависност од начинот на интеракција со дигиталните медиуми. Оваа студија ја опишува употребата на маркетингот преку социјалните медиуми како најчест вид на дигитален маркетинг што се користи за самопромоција на аптеките во Република Северна Македонија. Маркетингот преку социјалните медиуми служи за подигнување на свеста за одреден бренд преку вклучување на луѓето во онлајн дискусии. Најпопуларните платформи за маркетинг се социјалните медиуми Фејсбук и Инстаграм. За целите на анализата се користени податоци од профилите на Фејсбук и Инстаграм и од веб-страниците на 1000 аптеки. Овие податоци вклучуваат: содржина на профилот, фреквенција на објавувања на текстови и производи поврзани со здравјето, присуство на релевантни информации и линкови до страниците од кои е споделена содржината, фреквенција на објавување понуди и акции во аптеката. Истражувањето покажува дека употребата на Интернет како алатка за дигитален маркетинг во Република Северна Македонија не е доволно развиена, особено кога вебстраниците се користат како алатка за маркетинг и промоција на фармацевтскиот бизнис заедно со услугите кои ги нудат. Резултатите покажуваат дека Фејсбук како социјален медиум се користи најчесто за објавување здравствени совети, промоција на нови производи и одговарање на прашања на клиенти. Промоцијата на професионалните фармацевтски услуги е пониско ниво од промоцијата на производите, што доведува до недоволни податоци за спроведување на принципите на медицината базирана на докази во секојдневната пракса. 
